\title{
The Rota das Emoções in the touristic context of Northeast region of Brazil
}

\author{
Simone Cristina Putrick, André Riani Costa Perinotto*
}

\section{ABSTRACT}

Keywords:

Public policies,

Tourism,

Rota das Emoções (Route of

Emotions)

Northeast of Brazil.

\section{Article History:}

Submitted: 14.02.2021

Revised: 05.07.2021

Accepted: 20.08.2021

Published Online: 22.08.2021

\begin{abstract}
The objective is to analyze the importance of the Rota das Emoçoes in the development of Piauís territory. Piaui is studied in the context of the Northeast of Brazil, geographical space of Piaui and public tourism policies, with a focus on the Programa de Regionalização do Turismo (Tourism Regionalization Program) that suggests itineraries with the emergence of the Rota das Emoções (Route of Emotions), a regional route that comprises the Brazilian states of Piaui, Ceará and Maranhão. The relevance is given by the significant growth acquired by tourism in contemporary society. Governmental actions that promote territorial tourism diffusion are examined in Brazil, especially in Piaui. Private policies that regulate and establish tourist services that generate formal and informal jobs and trigger transformations with a multiplier effect. However, infrastructural transformations do not meet social objectives, directed to the market and to people's well-being.
\end{abstract}

Doi: https://doi.org/10.31822/jomat.2022-7-1-19

\section{Introduction}

This paper aims to investigate Rota das Emoções (the Route of Emotions) as a proposal for the socioeconomic development of the State of Piauí, based on Public Tourism Policies with a focus on the Tourism Regionalization Program, working on the territorial concept of tourism. It has the Northeast of Brazil as a context for analyzing tourism correlations with economic, social, political and geographical realities. This research is based on the type of principle of the gap in studies that understand the public policies that are behind the creation and maintenance of this route, it is expected that this article fills such questions in the literature so that the applicability of public policies for tourism in the region of fact come true.

The state of Piauí is one of the nine in the Northeast Region of Brazil. It has a history of political, administrative, economic, and commercial dependence, considered a marginal space for a long time, due to the situation of economic backwardness in relation to the other northeastern states, despite having a natural and cultural potential. For a long time, the formulation of public development policies is neglected in the national development project, with no transfer of federal resources to that State. The territory is part of the poorest region in Brazil.

In the 2004, public and private policies implemented $A$ Rota das Emoções, an integrated tourist itinerary, formed by the states of Ceará, Piauí and Maranhão, passing through fourteen cities. The implementation of $A$ Rota takes place with the economic and political restructuring of tourist activity in Brazil, by the Ministry of Tourism (MTur) with the Programa de Regionalização do Turismo (Tourism Regionalization Program) - Roteiros do Brasil (Tours of Brazil) - for the development of tourist activity, in the national territory, adopting the concept of tourist region to decentralize and diversify tourism products.

Brazilian Ministry of Tourism proposes tourist routing by creating routes for the union of dispersed tourist attractions, to organize and integrate the tourist offer in the country, and also to connect places with tourist potential, by offering profitable and commercially viable products. Thus, Rota das Emoções is installed, and it passes through three Conservation Units: Parque Nacional de Jericoacoara (Jericoacoara National

\footnotetext{
*Corresponding Author

Simone Cristina Prof. Dr., Parnaiba Delta Federal University, Avenida São Sebastião, 2819, CEP: 64202020, Reis Veloso, Parnaíba, Putrick: Piaui, Brazil, Email: sputrick4@gmail.com, Orcid Id:0000-0003-0891-7481 (D)

André Riani Costa Prof. Dr., Parnaiba Delta Federal University, Avenida São Sebastião, 2819, CEP: 64202020, Reis Veloso, Parnaíba, Perinotto: Piaui, Brazil, Email: perinotto@ufpi.edu.br, Orcid Id: 0000-0001-7094-3758 (D) 
Park), Parque Nacional dos Lençóis Maranhenses (Lençóis Maranhenses National Park) and Área de Proteção Ambiental do Delta do Parnaíba (Environmental Protection Area of the Parnaíba Delta) geographically close, suggesting complementation. Rota offers attractions in the segments of sun and beach tourism, adventure and ecotourism.

Political speeches, seeking to attract investments, through marketing, transform the image of the poor state into a tourist place full of natural attractions, however, not enough to end up poverty. The disordered occupation of the territory and the disarticulation of political, economic, and cultural factors aggravated by the concentration of income and power, intensify the picture of poverty (Andrade, 2005). So, capital, technical and technological limitations in the semi-arid region, together with the political backwardness, are responsible for maintaining the dominance and power of the oligarchies in the northeastern states, especially in Piauí (Araújo, 2013).

Governmental programs for the development of tourism, in different spheres, are now allocated in the Northeast Region. The activity gains economic relevance, in the formation of the positive image of the Brazilian Northeast. The possibility of exploring coastal landscapes induces the development of economic development policies and promotes the restructuring of the real estate market. The northeastern coast is converted into a tourist region with the adoption of development policies, with marketing strategies that value the shore (Dantas, Ferreira, \& Clementino, 2010). The transformation in this geosystem causes changes of both territorial and economic nature via tourism that emerges as an economic vector of the Northeast, which is evidenced by the volume of investments applied in tourism activity.

The Northeast Region structured in tourist hubs, concentrated in the coastal zone, where the beach, the sun and the sea become important variables for attracting tourists and moving businesses. In spite of this dynamic, Piauí remains poor and forgotten, so the objective of the text is to analyze the importance of $A$ Rota das Emoções in the development of the State. The geographical delimitation of the study area comprises the cities of Parnaíba, Luís Correia, Cajueiro da Praia and Ilha Grande, all of them in the State of Piauí, belonging to Rota das Emoções, from 2004 to 2019.

\section{Methodological Approach}

Content analysis is the basis of analysis and investigation in the search for a deeper understanding of the conception of critical and constructivist debate, as it presents a reality that is full of conflicts and contradictions (Triviños, 1987). Content analysis represents a technique for analyzing communications, with systematic procedures for describing the content of messages with knowledge of variable indicators (Bardin, 1977). Content analysis provides sufficient techniques to arrive at the true meaning of the message. Bardin (1977) says that this analysis is suitable for studying "de motivaçôes, atitudes, valores, crenças, tendências" (motivations, attitudes, values, beliefs, trends). Researchers necessarily identify ideologies contained in legal provisions, guidelines, principles that, in the simple scenario, do not present themselves clearly (Triviños, 1987). Thus, content analysis projects the reality presented in the territory contextualized in the research. Direct observation is a technique that elects representatives of public and private entities from the four municipalities of Piauí to access information generated by documents, articles, and projects in the study region.

For access to information, active projects, as well as conversations, direct observation is a technique that elects representatives of public and private entities from the four municipalities of Piauí, to capture maximum variation as well as a strategy for sampling and deepening issues relevant to Piauí. Rota das Emoções covered with advance determination of criteria about places and participants offers a greater view of the object investigated (Creswell, 2014) and issues raised. Systematic searches for relevant documents helped to understand the facts. The research was institutional and field search.

\section{Public, Private and Alternative Policies}

Public policies are ways of acting by the State focused on meeting the needs in order to offer dignified living conditions to citizens. Guaranteed not only by the State, but also by the executive bodies, they seek to ensure social rights for citizens. One of the main powers of the State is the police presented in the different regimes (liberal, orthodox), as a mediator of relations (Pereira, 2013). There are elements that are interconnected and compose the State, forming the:

$A$ set of institutions and prerogatives, highlighting the coercive power, delegated by the Society; the territory, understood as a 
geographically limited space where state power is exercised; a bureaucratic machine capable of administering government institutions and policies, collecting and managing resources; and a set of general conducts and behaviors that, regulated by the bureaucratic machine, help to create and maintain a common political culture, thus forming a nation (Souza Neto, 2018, pp. 95).

In a process full of contradictions in the relationship between civil society and corporate groups, because in the liberal-democratic State there are basic contradictions in the State-society relationship in the development of the forms of articulation of civil society and the functioning of the democratic mechanisms that legitimize the functions of the State. Meanwhile, the contemporary demands of overly complex social and economic structures expand the functions of the state. It is basically this contradiction that moves the liberal-democratic state (Costa, 2008, pp. 279) 1 .

The modern state has its origin in the 15th century, after the dissolution of empires and the end of the Church's domination, with changes in space and time. It is a politically, socially and legally organized institution. Sovereignly recognized, with no other authority in the territory that exercises this power, governed by the maximum law, the Constitution, with defined territory, a clear distinction between State and civil society, with explicit transience of government control in democracy (Bobbio, 2000). The landmark of the bourgeois expansion and the dissolution of the nobility occurs in the French Revolution. Trade becomes the driving force for development, an interest of the bourgeoisie, which establishes itself as a ruling class. The State exercises the infrastructure relationship, with the capacity to enter civil society, implementing political decisions throughout the domain (Mann, 1992). The way to enter society takes place in a regulatory manner, created and given by civil society itself.

So, the State tries, for its autonomy, to answer questions of minorities as the elite that looks for transformations, for which they cause elaborate actions that, many times, constitute public policies (Evans, 2004). Muller (2000) says that the policy takes place with plans, programs and projects in sectors of society and / or in regions and is based on a set of concrete measures. Streamline the territory, implement production. With territorial policies, it establishes new forms of production, which contribute to economic and social development or disagree with reality.

For the author, resource allocation decisions and State decisions are often made in an authoritarian manner. The State allocates resources according to interests, in a coercive way, to serve interests, especially companies. As much as there is popular pressure or social longing, social movements often break down, and changes occur as decided by the public sphere. Another view, the policy is placed in a framework of actions whose measure is isolated. In Costa's view (2008), public policy has functions and rules. Hall shows the 1950s Anglo-Saxon view of politics by saying:

It is a political activity influenced by the economic, social and cultural characteristics of society, as well as by formal government structures and other aspects of the political system. Politics reveals values and ideologies, power distribution, institutional structures and decision-making processes (Hall, 2001, pp. 26).

What differentiates European currents from Anglo-Saxon is the way in which the State was constituted for the currents and which social relations are considered and the weight they have. In the Anglo-Saxon current, public policy is what the State does, based on the minimum State, that is, the actions are aimed at the market. It is not the government's job to maintain basic needs, but companies. The Government's problems are the central issue of theories and political analysis.

In the European current, the State dominates society and shapes it. In the European perspective, the form of the State is to regulate social and class conflicts. For Muller (2000), the Government is the fusion that controls for some time: State is a bureaucratic mechanism. With the 1988 Constitution, there was a tendency to decentralize power over the public sphere, with the inclusion of civil society, educational institutions, and NGOs in the process of elaborating and implementing public policies.

The challenges for the regional roadmaps relate to an exercise in rethinking the complex information management system that allows, from existing sources and data collection, to obtain useful information for strategic decision-making by the government, managers and entrepreneurs. In this sense, the availability of local data allows the

\footnotetext{
${ }^{1}$ Free translation: meanwhile, the contemporary demands of highly complex social and economic structures expand the functions of the State. It is basically this contradiction that moves the liberal-democratic State.
} 
tourism sectors to better plan their investments, knowing the real demand and not just based on national averages that do not necessarily refer to the local reality. The development of smart tourism public policy requires the articulate participation of all relevant stakeholders, as well as strong political leadership to achieve broad collaboration and consensus (Alvares, Santos \& Perinotto, 2020).

The process takes place with the formation of forums, and thematic chambers made up of residents, businessmen, scholars, and representatives of the State. In these spaces, there is an attempt to expose, debate and reach consensus on the best to do for society. Policies against neoliberalism have human emancipation as their main elements, and work is a condition for survival and well-being. In tourism, this happens in community tourism, in which communities have production related to the primary sector. They present visitors with social relations, ways of working and tourist attractions of the place. Antihegemonic policies are opposed to the dominant process, with a view to a just, egalitarian and less competitive society. For Vieira, Putrick and Cury (2014, pp. 451):

Tourism is an activity capable of generating growth for places that make the practice of the activity viable, consequently promoting regional development. Depending on the context in which it is inserted, the term has a scope relevant to definitions and models.

The concept of development usually refers to progress, growth, especially regarding the economic situation. Cavalcanti (2003, pp. 26) explanes that [...] Efforts have been made in most countries of the world to provide economic development, which is considered [...] synonymous with economic growth 2 . Under this assumption, development is linked to the idea of freedom, when considering people's needs, and conditions that make them independent. Thus, for development to happen, the powers (public and private) work in partnership to implement development strategies. In tourism, among the development strategies are alternative policies that seek development, preservation of natural and architectural beauty. Tourism, as an alternative policy, is an opportunity to value and rescue traditions, folklore, cuisine, legends, stories. The elements of collective memory contribute to the strengthening of people's emotional bonds with the place. Issues like these are deepened in the community tourism debate One in which communities in an associative manner organize local productive arrangements, having effective control of land and economic activities associated with the exploitation of tourism. One of the first actions is to draw up an internal pact with all residents in defense of their properties. Everyone is committed to preserving the place, not getting rid of it, and those who really need to sell the house submit the business to the community, which analyzes who the buyer is, sees if it can be a partner, and how it can be partnership made (Coriolano, 2006, pp. 201) 3 .

Public tourism policies are a fissure of the State in the territory, with the premise of improving access to basic services for citizens and businesses. Private business policies fill gaps left by the State, in many cases, as a model of socio-environmental responsibility. They seek profits with increased consumption of services, with the inclusion of differentiated elements. Alternative policies developed in communities whose principles are linked to community well-being.

Public tourism policies of the municipalities of Rota das Emotions are analyzed in order to understand the conditions of expansion of tourist activity in Piauí, which uses changes in the political-economic organization. With the power of the business community, a new composition is made, in which the State and private initiative act in favor of tourism.

\section{Public Tourism Policies in the Northeast}

Tourism contributes to the composition of forces on scales ranging from global to local. Sun and beach tourism is the highlight of tourist demand. However, other segments such as religious tourism, events, rural tourism, have increased demand in recent years. According to Silva and Santos (2014, pp. 5) in the case of segments: nature tourism gain space among a group of people interested in getting to know certain places where nature is preserved and (or) preserved 4 .

\footnotetext{
${ }^{2}$ Free translation: from the 1930s onwards, [...] efforts were sent in most countries in the world to provide economic development, considered [...] to be synonymous with economic growth.

3 Free translation: One in which the communities in an associative way organize the local productive arrangements, having the effective control of the lands and the economic activities associated with the exploration of tourism. One of the first actions is to draw up an internal pact with all residents in defense of their properties. Everyone is committed to the preservation of the place, not getting rid of it, and those who really need to sell the house, submit the business for the appreciation of the community, which analyzes who the buyer is, verifies if it can be a partner, and how it can be the partnership was made.

${ }^{4}$ Free translation: in the particular case of segments: nature tourism gains space among a group of people interested in knowing certain places, in which nature is
} 
Following the global trend, tourism is included in the political and economic discussion agenda. The State considers strategic tourism policy as an economic activity, capable of generating foreign exchange, growth and economic development, through the restructuring of territories and the consumption of spaces. Natural beauties, history and culture can attract tourists, to contribute to the strengthening, dynamization and insertion of places in the globalized market (Coriolano \& Fernandes, 2005). In Brazil, the Ministry of Tourism recognizes the need for tourism to be included in strategic business agendas and develop public-private partnerships for tourism (Brasil, 2015).

The basic urban infrastructure that is essential to the resident's life serves to support the tourists who enjoy it, prepared based on public policies. The infrastructure attracts tourists, and organizes the space for setting up chains of restaurants, resorts, hotels. Tax benefits are among the state's strategies for attracting ventures to territories. With profit generated by the ventures, public policies, tourism marketing, mobilization of tourists, in some cases, communities, tourist territories are formed and consolidated (Putrick, 2019).

However, it is necessary to recognize the capacity of tourism to project transformations of territories, without a panacea to solve all the problems arising from a development model centered on the economy. Tourism development does not mean development, since no sectoral economic activity ensures global development that encompasses all dimensions of social life (Cruz, 1999).

Tourism continues to demonstrate the key role in generating economic activity. The European continent is the most sought after by tourists from all over the world $(51.8 \%)$ The main countries receiving tourists are France, the United States, China, Germany, the United Kingdom, Africa, and Russia in 2017. According to the World Tourism Organization in 2017, 1.3 billion tourists traveled the world. In relation to 2010 , there was an increase of $7 \%$. The number of visitors rose 84 million and international tourism revenues rose $5 \%$ (UN, 2017).

In 2017, exports generated by tourism reached US $\$ 1.6$ trillion (UN, 2017). So, tourism is the third largest export activity worldwide, with US \$ 4 billion per day. In the same year, Brazil had about
6.5 million visitors (UN, 2017). Revenues from tourism increased by $3.8 \%$ in the last seven years

In the list of 136 countries ranked according to the competitive potential of the various travel and tourism services, Brazil ranks 27th (World Economic Forum, 2017). Among the countries of South America, Brazil is the first on the list, leader of the world ranking of natural resources. The evolution of the country's rank, in the report, is expressive: in the 2013 edition of the Travel \& Tourism Competitiveness Report, Brazil occupies the 51st position.

In South American countries, as well as in Brazil, tourism is a relevant activity in the economic sector. According to information from the Ministry of Tourism, in the document entitled Estatísticas Básicas de Turismo Brasil (Basic Statistics of Tourism Brazil) - Base year 2015, there was an increase in activities related to tourism according to available data (Brasil, 2015).

The Northeastern macro-region of Brazil has broad potential for development in the field of tourism. The coast is a major recipient of tourism investments. The states of the region have great potential or tourist vocation, given the many attractions.

Northeastern territories, transformed into tourist destinations, have international and national recognition. The process results from actions, relationships and endogenous and exogenous factors, whose centrality of interests is antagonistic to that of residents (Cruz, 1999). Thus, hegemonic actions are exercised by groups outside the communities. Since tourism it is a geopolitical activity, it is not restricted to local interests.

The activity is made up of a large contingent of people to work in the services. The workforce in the Northeast is not fully trained. The conventional tourism organizational model, adopted by investors, caters to international and national tourists. Tourist spaces have been expanded with highways, facilitating travel and expanding tourist services. Tourism has been reconfigured to serve the tourist who visits the region, but in tourist areas, there is a lack of specialized services, which causes dissatisfaction and delay in the region (Putrick, 2019).

Tourism is planned, under the discourse of social improvements, expansion of jobs linked to the activity. With the internet, tourists see the place

\footnotetext{
${ }^{4}$ Free translation: in the particular case of segments: nature tourism gains space among a group of people interested in knowing certain places, in which nature is conserved and (or) preserved
} 
before visiting, but the media presents only spectacular spaces. In them, modern services of assistance to luxury tourism and communities are dependent on welfare policies, cistern projects or water supply by water trucks (Andrade, 2005).

The rural space has also undergone significant changes. From modernization, irrigated agriculture, expansion of soy cultivation by Bahia, Maranhão and Piauí; cattle ranching and the production of the timber industries cause deforestation and desertification. From the productive rural restructuring, there is a reduction in planting and harvesting time, quantitative expansion of products and increased profits (Elias, 2005). Contrary to the process, the disqualified workforce must migrate from the countryside to big cities, mainly to capitals, in search of work and conditions for survival.

Environmental problems, discontinuities and heterogeneities are common in the urbanization process of cities. Situations such as valuing spaces at the expense of others, denote contradiction in space and society. During spatial conflicts, medium-sized cities are formed (Putrick, 2019).

The coast plays an important role in the touristization of cities, being a tourist attractiveness. The formation of cities occurs through the configuration of networks, with the leakage and flow of people, capital, and goods. The coastal space is commercialized in capitalist relations of production, in which spaces, natural and cultural beauties become marketable products.

Spaces are competitive, with territories valued and selected by the capital. Yet others are neglected, uninteresting to investors, territories considered opaque. The representativeness of the dialectic relationship of the territory used is neglected territory. So, relations of production and reproduction of the territorial relationship regulated by globalized money and tourist spaces that expand the power of specific groups and territories are constituted.

In tourism, selected areas receive economic benefits from investment and financing from public-private partnerships, between the State and investors. Yázigi (2009) recommends that Brazil prioritize itself, its culture, identity and organization of the territory, so that subsequently it could meet the requirements of the tourist activity. The organization of the territory is fundamental for tourism and indispensable to the common inhabitant. It is not just an organization, but a procedure that requires politics, responsibility and the involvement of society.

The State of Piauí is one of the nine in the Northeast Region of Brazil, with a population of around 3,264,531 inhabitants occupying an area of $251,529,186 \mathrm{~km}^{2}$, distributed in 227 municipalities (IBGE, 2018). It presents geographical limits to the north with the Atlantic Ocean, to the east with Maranhão, to the west with Ceará and Pernambuco, and to the south with Bahia and Tocantins.

Basic needs issues such as: health, housing, education, tourism drive political planning and transformation of territories. However, political and economic crises, in the national context, raise issues about the efficiency of management, public policies, the credibility of institutions, transparency in public spending and in the State. Through planning, the State has an influence on the production and decision process in the territories. From the application of public policies, it attracts public and private investments, orders the territory in the development of activities such as tourism.

Piauí contributes with $0.7 \%$ of trips made in Brazil, the seventh lowest tourist emitter, among all the Federation Units. In terms of generating tourist revenue, its share is $0.8 \%$ of the country's total.

The highest percentage of tourists comes from the state itself, as well as the highest revenue generated is by tourists from Piauí. In the Documento de Caracterização e Dimensionamento do Turismo Doméstico no Brasil (Domestic Tourism Characterization and Dimensioning Document in Brazil), referring to 2014, the volume of domestic tourism consisted of 1,154,000 trips (Brasil, 2014). Piauí receives the smallest number of domestic trips in the Northeast $(1,157,000)$, including trips having their origin and destination in the state itself. In this sense, in economic terms, these data are alarming and worrying, which demonstrates the importance of working the Rota das Emoções, which has a huge potential to receive and attract tourists from around the world to increase these data.

The landscapes rich coastline has been strategic for the development of tourism, however an area of extreme vulnerability. Because it is a differentiated space, the state invests in infrastructure.

The coast of the State has tourist attractions, landscape heritage, lakes, ponds. On the coast 
there is a concentration of people, services and goods articulated in business and this intense occupation is called coastalization (Souza Neto, 2018, pp. 49) which is the expression of urbanization in coastal areas, mostly areas not intended for residents but for tourists 5 .

Tourist attractions, tourist equipment and services from the means of accommodation, food services, tourist guides, entertainment spaces and support infrastructure make tourism materialize in a tourist place, which is the position of production and consumption of the product, due to the dynamics of tourist activity (Fratucci, 2000).

The Rota das Emoções is the tourist itinerary of the Northeast, which goes beyond state geopolitical limits, integrating the states of Ceará, Piauí and Maranhão. It is inserted in the Tourist Region of the Mid-North, in the coastal strip that comprises the extreme west of Ceará, north of Piauí and northwest of Maranhão.

By the motivation of sun and beach tourism, ecotourism, sports and adventure tourism, the Rota das Emoções runs through three states and fourteen cities: Araiosés, Barreirinhas, Paulino Neves, Santo Amaro and Tutoia, in Maranhão; Cajueiro da Praia, Ilha Grande, Luis Correia and Paranaíba, in Piauí; Barroquinha, Camocim, Chaval, Cruz and Jijoca de Jericoacoara, Ceará besides institutions, associations, private agents and management bodies of three conservation units. The route reaches almost 1,200 km, between Fortaleza and São Luis, the main entrance gates in the route. The territory of coverage and distance, between the destinations of the Rota das Emoções, are represented schematically (figure 2).

It owes credit to the contribution of the tourist activity, in offering regional development to the reduction of regional inequalities, a discourse used in the national media. Under this pretext, governments invest in tourism, in the quality of socioeconomic development, believing in the power to collect taxes, fees and capital accumulation from the private sector (Coriolano, 2009).

It is important to recognize, however, that although tourism generates employment and contributes significantly to economic growth, it is not an automatic formula for poverty reduction. Tourism impacts on people affected by poverty: income generation; development of local / rural economies and people's livelihoods; it impacts on the natural and cultural environment in which they live (Putrick, 2019).

The Rota das Emoções, considered by the Ministry of Tourism as the best route in Brazil in 2009, competes with 90 routes. Launched by the Tourism Regionalization Program in 2004, the Rota das Emoções, in Piauí, was called Delta Selvagem (Wild Delta), and environmental education and community-based tourism development projects with professional qualification are planned.

The Rota appears as a strategy for the development of marginal areas, with less structured tourism products. Governments do not invest in infrastructure, in marginal areas, as basic needs such as road, water, electricity are prioritized. The private sector does not assume the investment burden that the authorities must provide. So, private investment remains in concentrated areas (Oppermann \& Brewer, 1996).

In Brazil, especially in the Northeast Region, investments in infrastructure have largely been directed to the capitals and centers that receive tourism. Nevertheless, the dispersion of tourists is important with the creation of new attractions since they diversify the tourist product. Besides, it expands the tourist's stay. In this way, they can offer opportunities for economic benefits (Putrick, 2019).

The development of the Rota das Emoções has an emphasis on the proposal to link and develop communities. The Structuring and implementation of routes can be developed by the public and private sectors, to increase the attractiveness of the area and the tourist product with the objective of generating income. In some cases, the Rota is not focused on community development. However, evolution broadens the focus, as it combines the development of a successful route with the expansion of connections with residents (Meyer, 2004).

The Structure and implementation of the Rota das Emoções is implemented by the public sector. The Rota's theme is not strong, it is not consolidated, and it does not go through any specific theme. The tourist activity develops in seasonal periods that include the period of school holidays, winter in the northern hemisphere and long-term holidays, which generates seasonal employment.

The product sold by the agents who sell the Rota das Emoções is uniform, turning Jericoacoara,

\footnotetext{
${ }^{5}$ Free translation: the expression of urbanization in coastal areas, most of which are areas not intended for residents and yes to the tourist.
} 
Delta do Parnaíba and Parque dos Lençóis Maranhenses the main attractions. It can be said that the Rota das Emoções aims to commercialize the main product, not being an opportunity to diversify it.

The main strategy for the development of the Rota is to form cooperative networks, with the purpose of offering diversified tourism. For its structuring, implementation, and maintenance, in each region, it is necessary to build and maintain collaboration between the State, private company, public institution, local council, association and community (Meyer, 2004). The arrangements can be formal or informal, between attraction owners, operators, and the food industry, with horizontal and vertical network links.

Cooperation is an element of structuring the Rota, in contrast, competition between suppliers and tourist attractions. World-class tourism planners and operators have presented collaborative models, as capable of expanding the benefits of tourism (Selin, 1993; Crotts, Aziz, \& Raschid, 1998). However, in the tourist activity of Rota das Emoções, collaboration and partnership are far from becoming a reality. Collaborative networks have not been formed, tourism is characterized by the infinity of small-scale businesses with highly diverse, common, and often competing operational practices and objectives (Putrick, 2019).

SEBRAE acts as an articulating body to promote entrepreneurship, in addition to guiding and promoting the destination of national and international markets, Sebrae's interlocutor affirms. However, it is known that the Serviço Brasileiro de Apoio à Micro e Pequenas empresas 6 (SEBRAE) is not responsible for development and structuring actions in the municipalities of Rota das Emoções. This role belongs to Agência de Desenvolvimento Regional Sustentável 7 (ADRS), a consortium formed by the states of Piauí, Ceará and Maranhão, created in 2006. The consortium develops integrated actions, planning and structure of the Rota das Emoções.

Collaborative networks, on routes, have been established because of the number of key individuals who act as a driving force and leaders (Meyer, 2004). The key individuals of the Rota das Emoções are no exception to the rule of collaborative networks. They are SEBRAE, businessmen, and representatives of the municipal departments of tourism, who work in a certain period of the structuring and implementation of the Rota das Emoções, but the replacement of representatives, due to the political issue, contributes to the discontinuity of the work.

The municipalities of Parnaíba, Luis Correia, Ilha Grande and Cajueiro da Praia have a Municipal Tourism Council, as governance instances, to comply with the legislation and keep the municipality able to receive federal funds. They are not involved in projects and programs that benefit the tourist activity of the municipalities.

Nevertheless, states and municipalities do not work together in the planning and implementation of cultural calendars, itineraries of regional circuits, marketing campaigns, and in the identification and treatment of issues related to tourism. The lack of regional collaboration reduces the political and economic capacity to deal with external public and private forces.

The elements for structuring the Rota are the development of innovative products, infrastructure, and access (Meyer, 2004). The structuring and implementation are dispersion strategies in tourism. They have become successful examples, linked to tourism, with an increase in the holiday period, means of transportation, search for cultural experiences, short day trips.

The production factors of the Rota das Emoções are based on natural and cultural attractions, with its diversity of natural resources, main attractions materialized in original landscapes, biological diversity, and the presence of endemic species. The routes establish a guidance system for travelers, although many are also visited by organized tours. It is a criterion that the product meets the needs of an untapped market for tourist sources, that is, an important asset of ecotourism, community tourism, cultural heritage, growth in tourism revenue, instead of just entering existing markets.

The concentration of visitors, on the Rota das Emoções, occurs in places where the main attractions are. The community must travel to the main attractions, or they are excluded from the process. No tourist inventory was carried out in any of the cities belonging to it. There is no mapping of craft points, mainly, there is no road connection between cities. The agencies do not argue, they do not have a clear vision of where they want to go. The main issues are a lack of financial resources and an inability to delegate responsibility; unfamiliar concepts of spatial

\footnotetext{
${ }^{6}$ Free translation: Brazilian support service for micro and small companies.

${ }^{7}$ Free translation: Regional Sustainable Development Agency.
} 
planning and formulation of regional strategies for development plans; lack of clarity of the role played by institutional representatives of tourism, at the federal, state, and municipal levels.

Infrastructure availability is a fundamental aspect of the development of the Rota. It means that the basic road or trail network must have a pattern that attracts and satisfies potential visitors. The Rota usually passes through secondary roads that offer a relaxed pace of travel. The road network is made up of landscape routes, which increases the tourist appeal, and makes the tourist choose it, as opposed to fast highways. Traveling along routes is an important product. The route needs to be chosen and designed on the attractive landscape. The landscape value is important for tourists (Meyer, 2004). For any route, infrastructure is crucial. This includes basic infrastructure, signage, rest area and sanitation.

In Rota das Emoções, the accommodation facilities are mostly in Parnaíba. According to Silva (2013, pp. 118), the coast of Piaui constitutes a functional territorial unit, in which the city of Parnaíba plays the role of the main support center for the realization of social, economic and service activities throughout this region.

Tourism activity is dependent on the hospitality of hosts, so community participation, in product development and decision making, is essential (Meyer, 2004), and occurs on scales, from passing on information, consultation and decision-making power. Entrepreneurship is necessary for tourism. Thus, the opening of new companies is necessary. Creating links, in many cases, is an initiative of external agencies, of public and private order. Achieving the financial sustainability of business ventures is one of the main factors of analysis. In some regions, there is a need for investment in basic infrastructure and facilities in marginal rural areas, in comparison to established tourist areas.

\section{Closing Comments}

The Rota das Emoções is an example that the lack of collaborative organization has been an obstacle to the integrated and coordinated development of tourism. Tourism organizations have little or no synergy. The lack of clarity regarding roles and responsibilities leads to duplication of development plans and a lack of integration. Without collaboration, it is difficult for those responsible for the institutions to know who to turn to in order to format the development proposal, single or integrated. This occurs at the state level and, in the case of Piauí, at the municipal level, due to the lack of global coordinating authority for the planning application process. Therefore, communities are unable to organize themselves in such a way that they cannot be contacted and communicated.

While the governments of the states do not take responsibility for the development of tourism, in the Rota das Emoções, it is possible to feel the inability of public intuitions to do so. Lack of authority, understanding and the ability to develop tourism were common criticisms during the research.

The route should be better delineated as a regional route, with intra-state and federal-state articulation in Brazil. Demand surveys are essential to understand how social, economic and tourist relations occur in the Rota region.

Tourism as a public policy has brought about minimal changes in the spatialization of the cities. The implementation of the Tourism Regionalization Program did not lead to the territorial deconcentrating of tourism. Although the State of Piauí is part of the Rota das Emoçoes, the tourist activity of the region is slow compared to its neighbors Ceará and Maranhão. Tourism is linked to the sun and beach, ecotourism, and adventure tourism segments. Although natural areas are the raw material for tourism, degradation problems are recurrent.

The complexity of political articulation becomes a challenge and highlights social and spatial differences, own government policies, different cultures, stages of tourism development and different work rhythms. In the realization of tourism, diverse social subjects are involved, including the local population, tourists, market agents and public authorities, with different, sometimes divergent, expectations.

In addition to understanding national public policies for tourism, regional routes should receive greater attention from the Federal Ministry of Tourism, in this sense it is important to carry out further research in the future by carrying out comparative studies of investments in regional tourist routes, in addition to benchmarking research relating to regional routes in Brazil.

Therefore, this research offers meaning as basic research material added to the conceptual framework that can be used to determine how public tourism policies in the study region can collaborate and contribute to better performing tourism. Thus, future research considers factors 
more diverse than those used in the current work, such as making comparisons with other destinations in the world that have regional networks of tourist routes.

\section{References}

Alvares, D. F., Santos, S. R.D., \& Perinotto, A. R. C. (2020). Network of tourism observatories toward tourism intelligence: the case of brazil. Enlightening tourism. A pathmaking journal, [S.l.], v. 10, no. 2, p. 140-178, dec. 2020. ISSN 2174-548X Available at: $<$ http://uhu.es/publicaciones/ojs/index.php/et/arti cle/view/4696>. Date accessed: 05 Jul. 2021. doi:http://dx.doi.org/10.33776/et.v10i2.4696.

Andrade, M. C. (2005). A terra e o homem no Nordeste: contribuição ao estudo da questão agrária, 7a ed., São Paulo: Cortez.

Araújo, E. F. (2013). “As políticas públicas de turismo na região Nordeste: novas ações do governo estadual cearense", in Revista Geografia em Atos, 1(13). pp. $22-35$.

Bardin, L. (1977). Análise de conteúdo, Lisboa: Edições 70, 1977.

Bobbio, N. (2000). Estado, governo, sociedade: para uma teoria geral da política, (trad. port. de Stato, governo, società. Per una teoria generale della política, por Marco Aurélio Nogueira, ed. original em 1985). 15a ed., Rio de Janeiro: Paz e Terra.

Brasil. (2014). Caracterização e dimensionamento do turismo doméstico no Brasil, Brasília: Ministério do Turismo.

Brasil. (2015). Estatísticas Básicas de Turismo Brasil, Brasília: Ministério do Turismo.

Cavalcanti, A. P. B. (2003). Sustentabilidade ambiental: perspectivas atuais de desenvolvimento, Teresina: UFPI.

Coriolano, L. N. M. T. (2006). O turismo nos discursos, nas políticas e no combate à pobreza, São Paulo: Annablume.

Coriolano, L. N. M. T. (2009). Arranjos produtivos do turismo comunitário: atores e cenários em mudança, Fortaleza: EdUECE.

Coriolano, L. N. M. T., \& Fernandes, L. M. M. (2005). Turismo: ações e contradições da realidade cearense, in J. B. Silva; T. Cavalcante; E. W. C. Dantas (orgs.). Ceará: um novo olhar geográfico, Fortaleza: Demócrito Rocha, pp.383-410.

Costa, W. M. (2008). Geografia Política e Geopolítica, São Paulo: Universidade de São Paulo.

Creswell, J. W. (2014). Investigação qualitativa e projeto de pesquisa: escolhendo entre cinco abordagens. Tradução de Sandra Mallmann da Rosa; Revisão técnica: Dirceu da Silva. 3. ed. Porto Alegre: Penso, 2014.
Crotts, J. C., Aziz, A., \& Raschid, A. (1998). “Antecedents of supplier's commitment to wholesale buyers in the international travel trade", in Tourism Management, 19(2). pp. 127-134.

Cruz, R. C. A. (1999). Políticas de turismo e (re) ordenamento de territórios no litoral do Nordeste do Brasil, Tese de Doutoramento, São Paulo: FFLCH - Universidade de São Paulo.

Dantas, E. W. C., Ferreira, A. L., \& Clementino, M. L. M. (2010). Turismo e imobiliário nas metrópoles, Rio de Janeiro: Letra Capital.

Elias, D. (2005). "Reestruturação produtiva da agricultura cearense: rumo à desintegração competitiva e à fragmentação do espaço agrário", in J. B. Silva; T. Cavalcante; E. W. C. Dantas (orgs.). Ceará: um novo olhar geográfico, Fortaleza: Demócrito Rocha, pp.429-461.

Evans, P. (2004). Autonomia e parceria: Estados e transformação industrial, Rio de Janeiro: UFRJ.

World Economic Forum. (2017). Travel \& Tourism Competitiveness Report, [Consult. a 13.03.2018]. Disponível em: http://blog.panrotas.com.br/mktdestinos/index.ph p/2017/04/07/brasil-ocupa-27a-posicao-emranking-de-competitividade-no-turismo/

Fratucci, A. C. (2000). "Os lugares turísticos: territórios do fenômeno turístico", in Revista GEOgraphia, 2(4). pp. 121-133.

Hall, J. (2001). Os Estados na história, Rio de Janeiro: IMAGO.

IBGE. (2018). Cidades Piauí (Instituto Brasileiro de Geografia e Estatística). [Consult. a 06.12.2018]. Disponível em: https://cidades.ibge.gov.br/brasil/pi/pesquisa/100 $60 / 60147$

Mann, M. (1992). "O poder autônomo do Estado: suas origens, mecanismos e resultados", in J. Hall (org.). Os Estados na história, Rio de Janeiro: IMAGO.

Meyer, D. (2004). Tourism routes and gateways: key issues for the development of tourism routes and gateways and their potential for Pro-Poor Tourism, Overseas Development Institute.

Muller, P. (2000). Les politiques publiques, 4a ed. Paris: Universitaries de France.

UN. (2017). Chegada de turistas internacionais atinge recorde de 1,3 bilhão em 2017, [Consult. a 13.03.2018]. Disponível em: https://news.un.org/pt/story/2018/08/1635612

Oppermann, M., \& Brewer, K. P. (1996). "Location decision making in hospitality using GIS - a paradigm shift?", in G. Prosseger (ed.). Australian Hospitality and Tourism Research Conference, 
Coffs Harbour, Australia: Bureau of Research, pp.279-288.

Pereira, P. A. (2013). Política social contemporânea: concepções e configurações no contexto da crise capitalista. In: Costa, L. C., Nogueira, V. M. R., And Silva, V. R., orgs. A política social na América do Sul: perspectivas e desafios no século XXI [online]. Ponta Grossa: Editora UEPG, 2013, pp. 15-26. ISBN 978-85-7798-231-8. Available from: doi: 10.7476/9788577982318.0001. Also available in ePUB from http://books.scielo.org/id/rfv9p/epub/costa9788577982318.epub.

Putrick, S. C. O. (2019). Turismo na Rota Das Emoções e no Desenvolvimento Socioeconômico de Municípios do Estado do Piauí. Tese de Doutorado em Geografia. UFPR.

Selin, S. (1993). Collaborative alliances: new interorganisational forms in tourism. Journal of Travel \& Tourism Marketing, 2(2-3). pp. 217-227.

Silva, M. M. M. (2013). O turismo nas ondas do litoral e das políticas públicas do Piauí, Tese de Doutoramento, Belo Horizonte: IGC Universidade Federal de Minas Gerais.
Silva, M. R. F., \& Santos, N. P. (2014). Demanda turística no Brasil e os caminhos para o turismo sustentável, in G. F. Seabra e A. P. Portuguez (orgs.). Turismo sertanejo: patrimônio cultural e realidade social em comunidades, Ituiutaba: Barlavento. pp.110-123.

Souza Neto, G. F. (2018). A modernização do litoral cearense: território, Estado e políticas públicas, Tese de Doutoramento, Fortaleza: PROPGEO Universidade Estadual do Ceará.

Triviños, A. N. S. (1987). Introdução à pesquisa em ciências sociais: a pesquisa qualitativa em educação, São Paulo: Atlas.

Vieira, A. F., Putrick, S. C., \& Cury, M. J. F. (2014). “A Geografia, o desenvolvimento regional e o turismo na Ilha das Canárias, estado do Maranhão-MABrasil”, in Geographia Opportuno Tempore, 1(2). pp.537-553.

Yázigi, E. (2009). Saudades do futuro: por uma teoria do planejamento territorial do turismo, São Paulo: Plêiade. 
2022, 7 (1): 19-29

https://doi.org/10.31822/jomat.2022-7-1-19

\title{
INFO PAGE
}

\section{The Rota das Emoções in the touristic context of Northeast region of Brazil}

\begin{abstract}
The objective is to analyze the importance of the Rota das Emoções in the development of Piaui's territory. Piaui is studied in the context of the Northeast of Brazil, geographical space of Piaui and public tourism policies, with a focus on the Programa de Regionalização do Turismo (Tourism Regionalization Program) that suggests itineraries with the emergence of the Rota das Emoções (Route of Emotions), a regional route that comprises the Brazilian states of Piauí, Ceará and Maranhão. The relevance is given by the significant growth acquired by tourism in contemporary society. Governmental actions that promote territorial tourism diffusion are examined in Brazil, especially in Piaui. Private policies that regulate and establish tourist services that generate formal and informal jobs and trigger transformations with a multiplier effect. However, infrastructural transformations do not meet social objectives, directed to the market and to people's well-being.
\end{abstract}

Keywords: Public policies, Tourism, Rota das Emoções (Route of Emotions), Northeast of Brazil

\section{Authors}

Full Name Author contribution roles

Contribution rate

Simone Putrick: Conceptualization, Methodology, Data Curation, Writing - Original Draft, Writing - Review \& Editing, $70 \%$ 